\title{
Baarhundertzeit: международная конференция, посвящённая 100-летнему юбилею доктора Йоханнеса Баара
}

Вот уже второй год, как человечество живёт под знаком угнетающей всех пандемии. Не случайно поэтому конференция, организованная в декабре 2020 года Отделом лексикографии современного русского языка Института лингвистических исследований Российской академии наук (Санкт-Петербург), была красноречиво названа «Неологизмы 2020 года: язык коронавирусной эпохи». Коронавирусная эпоха оставила глубокие борозды не только в языках мира (не случайно слово lockdown названо словом года), но и во многих ипостасях нашей жизни. Действительно, - нет языка, в котором бы не отразилось это явление на разных уровнях. Особо экспрессивно такое отражение наблюдается в современной фразеологии и паремиологии ${ }^{1}$.

При всей апокалиптичности случившегося научное сообщество и система образования в большинстве стран мира сумела преодолеть главный удар, наносимый пандемией, - строжайшую социальную изоляцию. Сумела преодолеть благодаря неудержимому стремлению к межнациональному и научно-педагогическому общению с использованием новейших цифровых технологий.

В самом деле: пожалуй, в сфере гуманитарных дисциплин никогда еще не проводилось столько конференций, конгрессов, симпозиумов и круглых столов, как в ушедшем 2020 году. Перенесённые весной на осень и зиму научные форумы успешно проводились в системе ZOOM, Microsoft Teams и др., оставляя информационные отпечатки во всех доступных on-line-публикациях. Участники таких форумов имели возможность и поделиться своими наблюдениями, и послушать и увидеть коллег, которых нередко не видели годы, а иногда и десятилетия.

${ }^{1}$ V. M. Mokienko, T. G. Nikitina (2021). Axiologie koronavirových antiprísloví. „Bohemistyka" nr 1, c. 97-116. 
Именно такого рода коллегиальное и дружеское общение было создано для немецких, русских и украинских русистов на конференции, организованной в небольшом северонемецком городе Тиммендорфер Штранд и Гамбурге руководителем известного семинара русского языка Кристиной Мильш при поддержке Гамбургской ассоциации преподавателей и переводчиков русского языка. Конференция прошла в дистанционном формате 7 февраля 2021 года и была посвящена столетнему юбилею выдающего немецкого гуманиста доктора филологии Йоханнеса Баара. 55 лет назад он основал Международный ежегодный семинар русского языка в небольшом курортном немецком городке Тиммендорфе недалеко от Гамбурга. Его основатель прошел путь от немецкого солдата, воевавшего под блокадным Ленинградом, до большого друга России, знатока русского языка, вице-председателя Федерального союза преподавателей русского языка ФРГ, почетного доктора СПбГУ (1990) и лауреата высшей награды Международной ассоциации преподавателей русского языка и литературы (МАПРЯЛ) - медали А. С. Пушкина. Методическое руководство семинаром в Тиммендорфер Штранде уже более 30 лет осуществляет филологический факультет СПбГУ, хотя в состав преподавателей входят профессора и доценты и других вузов.

Доктор Й. Баар - Человек-Эпоха, блестящий популяризатор русского языка, организатор семинаров русского и немецкого языков в Германии и Советском Союзе ${ }^{2}$. Он ушел из жизни в октябре 2018 года, успев в сентябре того же года последний раз приехать на семинар и поприветствовать его участников. Организаторы семинара и его многочисленные немецкие участники предвкушали осенью 2020 года отметить 55-летие семинара и 100-летний юбилей доктора Й. Баара в гостеприимном Тиммендорфер Штранде. Увы: Covid-19 вторгся в эти планы, сделав, казалось бы, желанное ежегодное общение с немецкими любителями и знатоками русского языка невозможным. Общение «вживую». Но - наперекор стихиям ковидного карантина - этим планам всё-таки суждено было осуществиться в формате он-лайн. Последовательно и целенаправленно преемница доктора

${ }^{2}$ К. Мильш, Б. Коваленко, В. Мокиенко (2019). «Уроки русского» доктора филологии Йоханнеса Баара. „Questio Rossica” № 2, c. 383-392. 
Й. Баара, руководитель семинара, член правления Ассоциации преподавателей русского языка города Гамбурга Кристина Мильш при активной поддержке Гамбургской Ассоциации преподавателей и переводчиков русского языка, а также слушателей и преподавателей подготовила программу онлайн-конференции, достойную Юбиляра.

Программа отразила «как в капле малых вод» практически весь научный и педагогический диапазон ежегодных двухнедельных семинаров русского языка. Более того, организаторы пригласили на конференцию преподавателей и слушателей, которые были участниками семинаров с момента его основания. В итоге получился масштабный обзор истории семинара, причём не только в его Stammstadte (городе-основателе), но во всех его филиалах, которые доктор Й. Баар организовывал в разных городах Советского Союза, преодолевая непреодолимые бюрократические торможения: в Симферополе, Петербурге, Киеве. Все эти «этапы большого пути» и были представлены в выступлениях участников этой памятной конференции.

Несколько слов о предыстории конференции. В курортном городке Тиммендофер Штранд недалеко от Гамбурга, уже 55 лет работает интенсивный двухнедельный семинар русского языка. Сюда съезжаются желающие изучать на разных уровнях (или просто поддерживать) русский язык не только со всей Германии, но и из Франции, Австрии, Швеции, Румынии. На протяжении многих лет на семинаре преподавали профессора и доценты из вузов Москвы, Петербурга, Казани, Екатеринбурга, Петрозаводска и Симферополя, в том числе К. А. Рогова, В. М. Мокиенко, С. И. Тимина, Н. А. Купина, Т. П. Кирина, Н. А. Куркова, М. В. Отрадин, А. Р. Петров, Г. А. Цветов, Н. С. Цветова, Н. Л. Федотова, Л. В. Миллер, В. К. Лебедев, З. К. Тарланов, В. А. Недзвецкий, Ш. Г. Умеров, В. А. Косова, И. М. Вознесенская, И. Г. Гулякова, Л. Н. Григорьева, Г. В. Липис, Н. М. Лейберова (Филиппова), О. А. Лазарева, П. Е. Бухаркин, Н. Н. Ромашов, В. В. Васильев, Л. В. Лошенков и другие преподаватели-русисты, культурологи, историки, политологи. Возглавляет группу преподавателей доцент СПбГУ, научный руководитель ДОП переподготовки по специальности РКИ Б. Н. Коваленко. Сюда приезжали с выступлениями писатель Фазиль Искандер, ректор, а затем президент Санкт-Петербургского университета и президент МАПРЯЛ и РОПРЯЛ Людмила Алексеевна 
Вербицкая, исполнители народной музыки из Вологды и Петрозаводска, члены различных русских музыкальных ансамблей и отдельные исполнители. Ежегодно участников семинара поздравляют бургомистр и представитель общины Тиммендорфа, а также консул России в Гамбурге.

Занятия делятся на утренние обязательные (фонетика, разговор, литература, страноведение, перевод) и послеобеденные факультативные (предполагающие более углубленное изучение отдельных тем из области искусства, литературы, истории, грамматики и т.п.). Между двумя парами утренних занятий проводится сорокаминутная «разминка-разрядка», когда слушатели собираются в самом большом классе, а то и на улице (если погода позволяет), чтобы хором попеть. Это и отдых, и работа: на таких спевках отрабатываются навыки произношения, расширяется лексический запас, запоминаются грамматические конструкции, происходит знакомство с русской культурой. А вечерами каждый день слушателям предлагается интересный фильм или лекция с последующим обсуждением, а также тематические вечера, из которых самыми любимыми стали музыкальный и литературный. Слушатели-иностранцы четырёх поколений проникновенно поют русские песни, выразительно читают стихи русских поэтов, с большим интересом участвуют во всевозможных викторинах и квестах, подготовленных преподавателями.

Место для проведения семинара тоже выбрано на редкость удачно: занятия можно совмещать с отдыхом, поскольку море и курортные пляжи даже в осеннее время привлекательны для прогулок и общения со слушателями, что, между прочим, также запрограммировано организаторами семинара. Красота этого местечка породила традицию совместной воскресной прогулки слушателей и преподавателей по «штранду», беседы во время которой продолжаются в уютном кафе.

Семинар в Тиммендорфе принимает всех любителей русского языка: есть здесь и начинающие (студенты и даже школьники), есть преподаватели, переводчики, дипломаты (нынешние и бывшие, которые, даже уйдя на покой, не расстаются со ставшим вторым родным для них русским языком).

Обстановка на семинаре невероятно теплая, дружеская, почти семейная. Некоторые слушатели регулярно посещают семинар уже 
в течение нескольких десятилетий. И основателем этого замечательного содружества является доктор Йоханнес Баар, который прошел долгий путь от молодого лейтенанта фашистской армии, воевавшего с русскими на блокадных подступах к Ленинграду, до ценителя, знатока России. История его обращения в русистику уже известна ${ }^{3}$. Доктор Й. Баар не дожил полутора лет до своего столетия, но успел отпраздновать пятидесятилетний юбилей семинара, который отмечался в 2018 году именно в Тиммендорфе и именно со слушателями. В свое время он передал руководство семинаром своей многолетней помощнице фрау Кристине Мильш, ставшей преданной хранительницей всех заложенных Й. Бааром традиций.

Именно Кристина Мильш и стала инициатором организации конференции в память о своем Учителе. Вместе со своими надежными помощниками Георгией Майс и Натальей Штурм Кристина Мильш проделала огромную работу, в результате которой десятки участников семинара встретились он-лайн для серьезного профессионального разговора и непринужденного общения в он-лайн формате.

Программа конференции была насыщенной и разнообразной. После обращений с приветственным словом к участникам конференции Б. Н. Коваленко (СПбГУ), Н. Н. Ромашова (Московский лингвистический университет), Е. Я. Титаренко (Симферопольский государственный университет) с сообщениями о биографии доктора Й. Баара и истории семинара выступила его руководитель Кристина Мильш. Профессор СПбГУ К. А. Рогова изложила свое представление о том, что есть «Русский язык сегодня»; профессор Московского государственного университета Ш. Г. Умеров проанализировал некоторые существенные моменты происходящих исторических перемен в области современной литературы; профессор СПбГУ В. М. Мокиенко провел семинар по фразеологии на тему «Русский язык и культура в зеркале фразеологии»; кандидат филологических наук Л. В.В.Лошенков осветил актуальные вопросы российской политики; профессора Н. Л. Федотова (СПбГУ), В. А. Косова (Казанский [Приволжский] федеральный университет) и доцент И. М. Вознесенская (СПбГУ) провели мастер-классы: занятия по русскому языку для начинающих,

\footnotetext{
${ }^{3}$ Мильш, Коваленко, Мокиенко, 2019.
} 
слушателей среднего и высокого уровня. Руководитель семинарского хора доц. И. Г. Гулякова (СПбГУ) исполнила сочиненную ею песню в честь доктора Й. Баара, созданного им семинара и продолжателей его дела. Ветеран семинара Ильзе Хоппе предложила участникам литературную викторину, продемонстрировавшую блестящие познания немецких слушателей в русской литературе. Другой ветеран семинара, бывший офицер Бундесвера, переводчик Георг Ваггерхаузер прочитал собственные стихи, выразившие его отношение к России.

О деятельности семинара в Симферополе и Киеве рассказали Т. А. Ященко и А. Бабич (Симферопольский государственный университет); соруководители семинара в разное время - Бирте Хильдебрандт, Гюнтер Якобс, Вольфганг Фрайберг - выступили со своими трогательными воспоминаниями о самых ярких моментах существования семинара.

По одной из многих сложившихся в Тиммендорфе традиций семинар открывается лекцией на тему «Русский язык сегодня». На этот раз такую лекцию прочитала почетный профессор СПбГУ К. А. Рогова. Приток новых заимствований, отметила докладчица, связан с различными жизненными ситуациями. Последний из них вызван эпидемией коронавируса, распространившейся по всему миру. Однако русский язык в очередной раз продемонстрировал умение приспособить заимствованные слова к своей фонетической, словообразовательной и грамматической системе. В докладе прозвучала также важная мысль о влиянии устной речи на письменную. Эллипсисы, перенесенные в письменную речь из устной, создают определенные трудности для понимания высказывания. Слово несет целый ассоциативный комплекс, становится своего рода сигналом, который восполняется знанием общей ситуации, контекста.

Л. В. Лошенков завоевал внимание слушателей семинара в Тиммендорфер Штранде своей эрудицией в области страноведения и политологии, его блестящие лекции и семинары для профессионалов-переводчиков, организуемые Ассоциацией переводчиков Гамбурга неизменно привлекают внимание десятков слушателей. На сей раз, умело используя как современный материал, так и классику, Л. В. Лошенков в докладе «Россия 2021: отцы, дети, записки сумасшедшего» охарактеризовал текущую политическую ситуацию в России 
и осветил самые последние события, волнующие не только российских, но и иностранных граждан.

Само название доклада Ш. Г. Умерова - «Обществу больше не требуется национальная литература?» - предполагало дискуссию. Используя данные ВЦИОМ и высказывания современных писателей, докладчик с тревогой констатировал резкое снижение интереса к художественной литературе за последние два - два с половиной десятилетия. Несмотря на несколько печальную общую тональность, в выступлении отчетливо прозвучала оптимистическая нота, выразившаяся в попытке наметить возможные пути нового возвышения роли писательского слова. Характерно, что резонанс немецких слушателей был более оптимистичным, ибо, по их наблюдениям, интерес к литературе - не только классической, но и современной - у их русских друзей и коллег не упал столь катастрофически, как кажется докладчику. При этом некоторые слушатели сами продемонстрировали хорошее знание русской литературы, приняв участие в подготовленной одной из слушательниц викторине.

С интересом приняли участники семинара и спецкурс В. М. Мокиенко об отражении традиционной русской культуры во фразеологии.

Практические занятия со слушателями разного уровня - основа и стержень семинара. Н. Л. Федотова, В. А. Косова и И. М. Вознесенская подготовили эталонные уроки для слушателей разного уровня на разные темы: «Компьютеры и Интернет: новая реальность», «О любви», «Слово ПАМЯТЬ и его языковое окружение». Н. Л. Федотова построила свое оригинальное занятие на материале фильма Никиты Михалкова «Неоконченная пьеса для механического пианино», в доступной форме введя для начинающих лексику по такой животрепещущей теме, как любовь. В. А. Косова основательно ознакомила обучающихся среднего уровня с лексикой, обозначающей человека и его действия, связанной с компьютером и работой в Интернете, а также показала словообразовательные процессы в этой области. И. М. Вознесенская предложила слушателям анализ лексического блока $n a$ мять, осветив вопросы происхождения, значения, сочетаемости, употребления, парадигматических связей и участия в фразеологии этого слова. Тема была проиллюстрирована текстами А. С. Пушкина, Ф. И. Тютчева, Ф. М. Достоевского и И. А. Бунина. Слушатели имели 
возможность сопоставить семантический диапазон этого концепта в русском и немецком языках.

Палитра конференции, посвященной доктору Й. Бару, как видим, была широка и красочна. Но, пожалуй, самым главным ее магнетизмом было общение четырёх поколений слушателей семинара - как друг с другом, так и с преподавателями, которых вот уже более полувека приглашают в гостеприимный Тиммендорф организаторы. Именно сочетание научной русистики, практического преподавания русского языка как иностранного и внеаудиторное общение представителей двух народов создает неповторимую атмосферу человеческого единения. И это - самый эффективный результат конференции, убедительное доказательство того, что дело всей жизни немецкого гуманиста доктора Йоханнеса Бара и его последователей не затихнет и что семинар продолжится «вживую» после завершения карантина. Продолжится, ибо участники конференции давно уже привиты самой целебной вакциной - вакциной взаимопонимания между народами.

Ирина Геннадьевна Гулякова Валерий Михайлович Мокиенко 